\title{
Potential of synergistic didactics in social and humanitarian knowledge
}

\author{
Tatyana Eroshenko ${ }^{1, *}$, Anastasia Melnik ${ }^{1}$, Ekaterina Titova $^{1}$, Tatyana Zhukovskaya ${ }^{1}$ \\ ${ }^{1}$ Don State Technical University, 1, Gagarin Square, Rostov-on-Don 344000, Russia
}

\begin{abstract}
The article raises the problem of forming a new didactics on the methodological basis of synergetics. The new didactics should reflect the cognitive features of the perception of the modern generation, the features of socialization of modern youth. The authors reveal the difference between the new didactics and the old, classical didactics. The methodological and methodological basis of the new didactics is the gnoseological tools of modern post-non-classical science. The sociology course program is considered as a practice of implementing the new didactics, which is one of the central courses in the concept of social and humanitarian knowledge in higher education institutions. Our task is to look for the possibilities of this new didactics based on the conceptual directions of the post-non-classical paradigm. Synergetics as a methodology that actually functions in scientific and educational practice can be divided into two branches: formal synergetics and metaphorical.
\end{abstract}

\section{Introduction}

The fundamental problem of modern school in the broadest sense of the word is the growing workload of students from year to year. The amount of student workload is beyond the capacity of the organism. Moreover, the psyche of students is constantly (and not only theirs) bombarded with extraneous noise (spam), which additionally tires and interferes with the perception of useful information. Some of the factors that cause student overload can be attributed to subjective factors and some to objective factors. The subjective ones include the teacher's unprofessionalism, his inability not to overload the student unnecessarily, his lack of knowledge of advanced learning technologies, overloading with optional types of education. Objective ones include the quantitative growth of knowledge and experience that form a culture that a person needs to master in order to socialize in modern society [1-4]. The problem is that the modern generation is not able to perceive large amounts of information, for example, an academic lecture given without visualization. They will not be interested in long lengthy arguments and speeches, which make them quickly get tired of. The perception of modern students is aimed at a bright visual image, which is how they are used to more effectively perceive and assimilate information. Thus, the generation of modern students has developed different ways of receiving, perceiving and assimilating information as well as ways of thinking and understanding than the previous generations, which is one of the main reasons for the problems faced by the higher education system today [4-13].

\footnotetext{
* Corresponding author: eroschenko-1970@mail.ru
} 
The subject of our research is connected with the objective factors. The influence of the objective factors on the growth of student workload is not only a pedagogical problem, but also a general cultural one, being the problem of packing ever-increasing amounts of human knowledge and experience into user-friendly forms. This problem cannot be solved only by the traditional logical-didactic and methodical methods. Ways to solve this problem should be sought, of course, without abandoning the improvement of traditional techniques, but to a greater extent in the penetration of new didactics into the school, based on new general cultural and scientific paradigms.

Our task is to look for the possibilities of this new didactics based on the conceptual directions of the post-non-classical paradigm. The new didactics should include the experience of classical traditional didactics, its traditional forms adapted to the use of electronic technology in the transmission of educational content.

\section{Materials and methods}

Until now, the idea of social synergy has been widely spread as a "transfer" of concepts born in the space of natural science to the description of super-complex systems and processes occurring in society. It is generally assumed that natural science synergetics was originated in the $60 \mathrm{~s}$, and social synergetics began to form later only in the late 80 -early $90 \mathrm{~s}$. Humanitarians were particularly attracted to describe with the help of synergetics the emergence of a new order in the chaos and the possibility of predicting events in the historical process of wave-like cycles. However, the accumulated experience of using methods of social synergetics in research and the staggering speed of development of social events in our time, which continues to increase, suggests another model of synergization of knowledge of social systems and processes, which was born implicitly within the socio-anthropological space itself.

We assume that the synergy of society or social synergy was born before the term for it appeared. Moreover, we consider the concept of social synergy in two ways: first, as a prescientific or scientific knowledge system that studies the manifestations of synergy of processes and, secondly, as the art or practice of social synergy. Social life is essentially generated by synergy and resists the degradation and disintegration that are threats of aggressive natural and socio-cultural environments. True social life is always a socialanthropological life, and social-anthropological life is always a synergy of the individualpersonal and collective, social ones. The above allows us to distinguish two branches of social synergy: as theory and as practice, i.e., experience or skill.

So, the following types of knowledge or theory can be distinguished: religiousmythological synergetics, social-utopian synergetics, scientific social synergetics. As a practice: synergetics of "simple" societies, synergetics of "complex" societies, and synergetics of super-complex "global" societies. The identification of types of synergetics as both knowledge and practice is conditional. In reality, we are dealing with syncretic types: both synergetics as knowledge and synergetics as practice. For developed forms of social synergy, the problem becomes the implementation of the synergy of already accumulated experience: both as knowledge and as practice.

The first branch is all kinds of human knowledge, ideas about the structure and processes in the socio-anthropological space, information about successful and unsuccessful experiences of social construction. The second branch is the practice of using methods of synergy, a real technology of synergy, determined, of course, by the level and state of human experience and knowledge. The positive and negative experience of synergy, generalized and recorded in one form or another, becomes a theory, knowledge.

In a "simple" society the main source of knowledge and ideas is the practice captured in traditions, myths, religious values and rituals. Under the conditions of "complex" society the 
idea of synergy methods is formed under the influence of the achieved level of all forms of human social consciousness, scientific and extra-scientific knowledge and experience. The main problem of synergy in a simple society was natural factors: such as the desire to protect themselves from external negative natural factors and to curb the internal nature of zoological individualism, which is incompatible with being in the socio-anthropological space. In a complex society, social conflicts come first due to the emergence and development of social inequality, although the need to simultaneously confront natural factors persists and may even increase. Despite the importance of the natural-scientific image of synergetics, which provided an impetus to the development of scientific knowledge in the second half of the twentieth century, this image was born on the description of a more "simple" reality than the socio-anthropological one. Reconstruction of synergistic processes in the history of science will clarify the methodological aspects of synergetics that are most appropriate to the features of the modern socio-anthropological space, which will make it easier for humanitarians to accept and assimilate the system of research values, logic and methodology of modern educational programs.

Is there any theoretical evidence of the real existence of the model of pre-scientific synergetics, which we stated at the very beginning? Yes, there is. And we find such an example in a field far removed from natural science and mathematics. In modern synergetics, in its relation to mathematics, two types are sometimes conditionally distinguished: formal (mathematized) and informal (metaphorical). S. Khoruzhey drew attention to unnatural scientific synergetics. "Along with this, synergy had a completely different life, quite explicit and open, which began many centuries before the appearance of synergy and continues with some interruptions to the present day. This other life took place in another sphere, not so well known and popular as synergetics: in the sphere of Eastern Christian thought. Here its history was rich and its role was very significant: synergy is one of the key concepts of Eastern Christian spirituality and worldview. This concept is born in Greek Patristics and early Christian asceticism and has a special nature, which combines the theological and practical, that is, experimental and anthropological, dimensions..." [14]. It is obvious that the synergetics identified by S. Khoruzhey is only a particular and specific type of synergetics of medieval societies, revealed by him in the experience of Hesychasm (one of the mystical teachings). This "experience is ontological" because it is "the experience of being, the expression of the primary being attitude, the global anthropological orientation; having an energetic, active nature, it is endowed with the possibility of practical implementation, deployment of this orientation and installation in all existing forms: this is the self-realization of man" [15]. We believe that excessive universalization of the presented experience is dangerous, but synergistic experiences of the past in general, not only hesychasic, but also others, can be useful for "practical implementation". The era of "historical spontaneous social synergy" as social creativity has been opened.

\section{Results}

Synergistic didactics requires a combination of competencies from the teacher: teacherdidact-scientist. The teacher in these three guises must have the art of synergizing the content of the educational material. From the history of didactic triumphs in the past we cannot ignore two facts. In the teaching of natural sciences a brilliant example is the discovery of D. I. Mendeleev's "Periodic table of chemical elements". By synergizing i.e. combining all the material about chemicals and fractalizing it, highlighting the elements as fractals, D. I. Mendeleev presented all the complex variety of physical and chemical processes in the form of his famous table. In humanitarianism an excellent example is K. Marx's representation of the development of capitalist society from a cell (fractal), which he presents as a commodity. 
An excellent example of the art of synergization and fractalization of the content of educational material is the work of Budanov V. G., devoted to the problem of presentation in the course "Concepts of modern natural science" of the evolution of disciplinary knowledge. He proposed the descriptive and geometric models of the evolution of natural science knowledge as a process of interdisciplinary coordination. The fractals of interdisciplinary coordination are clearly visible in the geometric model [16]. And in the process of teaching and learning it is very important to use the ability to represent the simplicity of the complex. The basis for this is the basic concepts of synergetics and, to a greater extent, the concept of "fractal", which helps to convey the simplicity of the complexity, explaining that each phenomenon reflects the essence of the entire process or fact. The reason for this is the peculiarities of "clip thinking" in modern students, which means that they are ready to perceive information fragmentally, briefly but at the same time in a bright and exciting form. Thus, the condition for successful perception of lecture information is, in our opinion, its ease of perception, accessibility, simplicity and visibility. The global flow of information coming from outside needs to be systematized by focusing it in a graphic image, which contributes to its assimilation in a short period of time. This function can be performed by infographics, compactly summarizing the material, without losing the integrity of the meaning of the information received. It seems to us that the introduction of elements of synergistic modeling into the daily life of higher education is already being implemented and it can be useful. The school is the largest laboratory for testing the conceptual directions of the post-non-classical paradigm. In the current situation, when the social sciences are under the pressure of "pluralism" of paradigmatic attitudes and their methodological tools are characterized by continuous changes, the transposition of the content of a scientific discipline into an educational discipline appears to teachers as a non-trivial task of social creativity [17-22].

Let's consider the transposition of the content of science into an academic discipline using the example of sociology. The basis of the didactic model of the course in sociology should be a problem-oriented program for describing, analyzing and explaining the social transformations taking place in society. The effectiveness of such a program is ensured by the use of a system of concepts and categories that most deeply penetrate into the essence of unstable social reality, and actually make up the sociological method. Every science in the production of new knowledge is subjected to the certain general rules. These rules are also transferred to the learning process. The most widely used method of cognition in modern science is modeling, i.e. representation of the "unknown" (complex) by means of a construction of "familiar" (relatively simple) elements. An analog of scientific modeling is didactic modeling. In our example, i.e. in didactic modeling of sociology, we use a number of basic synergetic concepts: "evolving system" ("evos"), "genome of an evolving system" ("gevos"), "fractal", etc. "Evos" is a concept that denotes an indefinite set of open, nonequilibrium, non-linearly changing systems that exist in the world. It is believed that in the structure of evos it makes sense to identify the most stable part of it: the invariant core or genome of evos (gevos). Sociology can use the terms "social evos" and "social gevos" respectively. The evos genome is a program for the development of evos and at the same time stands guard over its integrity. The concept of "fractal" is genetically linked to many scientific and philosophical concepts: "a fundamental principle", "atom", "molecule", "cell", "cell". In the fractal you can see a reflection of the entire structure of evos. The fractal represents a new level of generalization of knowledge about the primary elements of reality: changing, continuously moving, proportionally repeating [23].

At the theoretical level from the point of view of the concept of fractals cognition in sociology is the construction of fractal "patterns-images", models of socio-anthropological reality. Every concept, theory, and paradigm that describes society is another representation of a "fractal pattern-image" model that approaches reality, is verified or rejected by subsequent practice. At the empirical level, the construction of the so-called "sample" is 
nothing more than an example of the formation or formation of a fractal of socioanthropocentric reality, as its model, which will allow us to see directly some of its supposed properties. Sociology is transformed into an academic discipline in the educational space of higher education. The teacher in the process of teaching transforms sociological information into knowledge, creating meaningful schemes of its interpretation and causes students to strive to develop their own opinion about the learned information. Moreover, sociological knowledge in the educational space, ultimately, must have the ability to awaken the creative potential of the individual. Students need to be helped out of the captivity of everyday consciousness to look at the social world in which they are embedded, through the eyes of science: to see and appreciate the world around you and yourself in it.

Sociology, like any other science, appears as a system of knowledge, i.e. a system of concepts, categories, concepts, principles, laws, and theories that reflect, describe, and explain a particular locus or fractal of objective socio-anthropological reality. Such concepts as" social system"," social structure"," social relations"," social status"," social institution"," social organization"," social role"," socialization", etc., highlight a special aspect of objective reality that can be defined as "social". We believe that it is still relevant to use the concept of "sociology" to refer to the entire set of social sciences or rather social and humanitarian sciences. We use the concept of "socio-anthropocentric knowledge" in terms that are close to the broad meaning of the terms "sociology" / "social science" and "social and humanitarian sciences". To denote the subject of this complex of sciences the term "socio-anthropological reality" is used. This situation reflects the fact that relationships, interactions and social anthropology, the continuity of human existence and existence of society, i.e. the environment was created by man for himself. This situation also reflects the real mutual transitions of scientific disciplines, the interaction of two trends in the scientific space: integration and differentiation of scientific knowledge.

Most sociological concepts are fuzzy and blurry. The vagueness of sociological concepts is not the result of sloppy work by sociologists, but an objective reflection of the properties of social reality: its fluctuations, fluidity and shocks. Concepts that display complex objects are often not sufficiently defined. The concepts of sociology are not only unclear, but also have the property of inter-crossing and flowing into each other or branching into broader concepts. For example, category: community $\leftrightarrow$ social group $\leftrightarrow$ society $\leftrightarrow$ personality $\leftrightarrow$ society $\leftrightarrow$ world system $\leftrightarrow$ world civilization, etc. In the light of synergetic theory sociology itself as a theoretical system refers to spiritual evos and fractals, spiritual facts of the social.

According to the main general scientific paradigms in sociology there are: (0) preclassical, (1) classical and (2) non-classical sociology. We can also talk about the formation of (3) post-classical sociology. But within itself sociology breaks down into internal paradigms - emerging concepts, theories: social action theory, structural functionalism, Marxism, neo-evolutionism, understanding sociology - symbolic interactionism, phenomenological sociology, behaviorism, etc. According to the research goals the following ones are distinguished: the fractal of fundamental and the fractal of applied sociology. According to the size and scale of objects of socioanthropological reality -macrosociology and fractals of microsociology that make up the macrosocial. According to the degree of theoretical abstractness the following fractals of sociology differ: general sociological theory, special and branch sociological theories or middle-level theories, and empirical sociology. The examples of sociological concepts fractalization are given in the following Table 1: 
Table 1. The examples of sociological concepts fractalization.

\begin{tabular}{|c|c|}
\hline Microfractals of the social & Macrofractals of the social \\
\hline Social groups & Community \\
\hline Family & World system \\
\hline Personality & Civilization \\
\hline
\end{tabular}

\section{Discussion}

So, at the end of the last century philosophers and scientists state the beginning of the formation of the post-non-classical paradigm. Apparently, both science and culture are only at its threshold. In the post-non-classical paradigm itself there are three conceptual directions that acquire themselves the status of paradigms: 1) the theory of the non-stationary Universe; 2) synergetics; 3 ) the theory of biological evolution and the concept of the biosphere and noosphere developed on its basis.... The post-neoclassical paradigm and its brainchild, the interdisciplinary theory of "synergetics", continue to be the subject of endless debate: from excessive admiration for its capabilities to accusations of fetishism by its proponents. Special attention of scientists is drawn to synergetics, which is called the core of post-classical science. Excessive and insufficiently competent fascination with the concepts of synergetics gives rise to the term "synergetic syndrome" in pedagogy. We believe that this is the cost of growth. Synergetics as a methodology that actually functions in scientific and educational practice can be divided into two branches: formal synergetics and metaphorical. Metaphorical or informal synergetics is most suitable for educational practice, not only because many teachers, with the exception of those with higher physical and mathematical education, find it difficult to fully use formal synergetics, but also because the absolute majority of students also find it difficult to perceive the content of formal synergetics. In addition, humanitarianism has its own recorded informal way of moving towards post-classical studies. We propose to distinguish between synergistic didactics, based mainly on metaphorical synergetics, and synergistic didactics, based on formal synergetics. Not everything that stands for synergistic didactics is actually this kind of didactics. Synergy practice is based not only on natural science experiments, but also on the metaphorical discourse of Hesychasm and the Eastern religious and philosophical tradition. The formation of a new didactics is difficult and contradictory. The problem of student overload provides an opportunity to test the heuristic and integral properties of the synergetic paradigm settings. Let's look at examples of existing practice of using synergy concepts in training.

\section{Conclusion}

So, a really new didactics can be called equally "post-non-classical" or "synergistic didactics". One of its leading concepts is the synergization of the content of educational material. In this case fractalization appears as an element of synergy. If you try to distinguish the leading difference between old and new didactics, it is the following: in classical didactics the teacher teaches the knowledge of the complexity through the simplicity or from simple to complex, and in post-nonclassical didactics he teaches to understand simplicity of complexity.

\section{References}

1. K. Meteshkin, A. Sokolov, O. Morozova, N. Teplova, Journal of education, health and sports 6(7), 375-390 (2016) doi: 10.5281 / zenodo. 58067 
2. S.Yu. Kamianetsky, RUDN journal of Informatization of education 16(1), 64-72 (2019) doi: 10.22363/2312-8631-2019-16-1-64-72

3. E.V. Voevoda, Discourse and communication 2(2), 89-94 (2020) doi: 10.24833/26870126-2020-2-2-89-94

4. D. Baczała, Przegląd Badań Edukacyjnych 1(26), 7 (2018) doi: 10.12775/PBE.2018.001

5. M. Ferrari, L. Vuletik, The developmental relations among mind, brain and education (Springer, Dordrecht, 2010) doi: 10.1007/978-90-481-3666-7

6. M. Ferrari, Development and its relation to mind, brain, and education: continuing the cork of Robbie case (Springer, Dordrecht, 2010) doi: 10.1007/978-90-481-3666-7_14

7. A. Özdoğru, Journal of Neurobehavioral Sciences (2014) doi: 10.5455/JNBS. 1408373410

8. Jia Jia Xiu, Liang-Cheng Zhang, European journal of psychological assessment in the press (2015) doi: 10.1027 / 1015-5759/a000268

9. F. Cano, Psychology, medicine The British journal of educational psychology 75, 20321 (2005) DOI:10.1348/000709904X22683

10. G. Giampietro, European journal of cultural and political sociology 3(2-3), 1-5 (2016) doi: 10.1080/23254823.2016.1209886

11. A. Person, Framing social interaction. Continuities and cracks in Goffman 's frame analysis (Liber, London, 2018) doi: 10.4324/9781315582931

12. G. McKenzie, Interpreting Charles Taylor's social theory of religion and secularization, 133-167 (2017) doi: 10.1007/978-3-319-47700-8_6

13. A. Portes, M. Zhou, Annals of the American Academy of political and social Sciences 530(1), (2010) doi: 10.1177/000271629353000106

14. S.S. Horuzhiy, Questions of Philos. 12 (2011) // http://vphil.ru/index.php?id=435\&option=com_content\&task=view

15. S.S. Horuzhiy, To the phenomenology of asceticism 6 (1998) // https://predanie.ru/horuzhiy-sergey-sergeevich/k-fenomenologii-askezy/chitat/

16. V.S. Budanov, Model of evolution of disciplinary knowledge as a process of interdisciplinary coordination //http:/www.synergetic.ru/science/model-evolyuciidisciplinarnogo-znania-kak-processa-mezhdisciplinarnogo-soglasovania.html

17. T.S. Nazarova, V.S. Shapovalenko, "Synergetic syndrome" in pedagogy http://www.portalus.ru/modules/shkola/rus_readme.php?subaction=showfull\&id=1192 627932\&archive $=1196815384 \&$ start_from $=$ \&ucat $=\&$

18. O.V. Erokhina, D. Mukhametov, A.V. Sheremetev, 2019 Wave electronics and its application in information and telecommunications systems (WECONF) (2019) doi: 10.1109 / WECONF.2019.8840644

19. G.P. Williams, Journal of World-Systems Research 19(2), 202-210, (2015) doi: 10.5195/jwsr.2013.491

20. S. Dale, Comparative Strategy 31(5) (2012) doi: 10.1080/01495933.2012.731976

21. W.I. Robinson, International Sociology 26(6), 723-745 doi: $10.1177 / 0268580910393372$

22. N.G. Osipova, Bulletin of MSU Series 18 Sociology and political science 25(4), 124153 (2020) doi: 10.24290/1029-3736-2019-25-4-124-153

23. J. Stepnisky, The Wiley Blackwell Companion to Sociology (Wiley-Blackwell, 2019) doi: 10.1002 / 9781119429333 . ch2 
24. V.E. Voitsekhovich, Synergetic concept of fractals (social and philosophical foundations). Synergetic paradigm. Man and society in conditions of instability (Moscow, 2003) https:/http.biblioclub.ru/index.php?page=book red\&id $=445108 \&$ razdel $=141$ 